\title{
An Evaluation of the Relationship between Human Resource Practices and Service Quality: an Empirical Investigation in the Canadian Hotel Industry
}

\author{
OSAMA KHASSAWNEH ${ }^{1 *}$ and TAMARA MOHAMMAD ${ }^{2}$ \\ ${ }^{1}$ School of Business, American University of Ras Al Khaimah, Ras Al Khaimah-UAE. \\ ${ }^{2} S c h o o l ~ o f ~ B u s i n e s s$, American University in the Emirates, Dubai-UAE.
}

\section{Abstract}

Human resource (HR) practices have been recognised as a key function in enhancing organisational productivity and competitive advantage. It has been noted that most studies that are based on the relationship between HR practices and performance indicators (e.g.,service quality) in hotels hide an important element that tells hoteliers which factors to concentrate on in cases of poor performance. Ourstudy aimed to examine the influence of HR practices on service quality in the Canadian hotel industry. This study seeks to investigate how HR practices (recruitment and selection, training, rewards and incentives, and internal career opportunities) help to improve the service quality. We used a qualitative method by establishing three sets of semi-structured interviews to obtain data from the top to the bottom of the hierarchy within hotels. We found that HR practices help in delivering high service quality. A key contribution of this study that it offers a workable definition of service quality and then a robust model for the relationship between HR practices and service quality that contributes to enhance knowledge of the causal relationship between them. In addition, our study contributes by identifying which HR practices a hotel could adopt to gain a service quality advantage in the marketplace. The data gathered for the proposed study may limit the findings' applicability to independent hotels that are not affiliated with international hotel chains. However, because of the low number of empirical research and the need to get a deeper knowledge of the link between HR practices and service quality, generalisation of the findings from the current descriptive-qualitative study is not a concern. Further research may include some control and context variables (e.g., hotel ownership type, position level, gender) that we did not include in this investigation. In addition, in the future, we recommend using mixed method (quantitative and qualitative) in order to come up with more generalisable results.

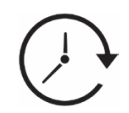

Article History

Received: 30 June

2021

Accepted: 03 August

2021

\section{Keywords}

Canada;

Career Opportunity;

Hotel;

Hr Practices;

Recruitment;

Selection;

Service Quality.

CONTACT Osama Khassawneh osama.khassawneh@aurak.ac.ae Khaimah, Ras Al Khaimah-UAE.

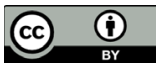

(C) 2021 The Author(s). Published by Enviro Research Publishers.

This is an Open Access article licensed under a Creative Commons license: Attribution 4.0 International (CC-BY).

Doi: http://dx.doi.org/10.12944/JBSFM.03.01-02.08 


\section{Introduction}

The hotel industry is experiencing tremendous transformation in terms of the quality of its services and its response rate to the customer's needs (Mokhtar and Sjahruddin, 2019). These improvements in the quality of services rendered in organisations generally depend heavily on the role of the human resources (HR) department, which controls the employee relations system (Abdul et al., 2018). HR managers in the hotel industry are now placing a lot of emphasis on their HR practices to ensure service quality, and the decision to apply such a focus follows the core realisation that employees are vital to achieving a high level of service quality (Rahman et al., 2019).

Admittedly, a number of studies (e.g.,Ding and $Y u$, 2021; Francis and Baum, 2018; Sebastiampillai and Holm, 2017)have carried out related research in recent times, but only a few of them have actually investigated the relationship between $\mathrm{HR}$ and the performance of their employees in delivering service quality as seen from the perspective of both the employees and HR managers. Nadda et al. (2014) investigated the relationship between HR practices and employees' performance in British hotels. In addition, Al-Refaie (2015) examined the effects of HR on hotel performance using structural equation modelling and determined that there is a positive relationship between the variables. In addition, Zhang (2017) implemented a study on HR and performance in the UK hotel industry and found that there is a strong relationship between HR practices and service quality delivered by hotels. Therefore, the study serves as an extremely necessary line of enquiry given the importance of an effective HR department in an organisation.

There were approximately 8,178 hotel properties in Canada by 2016 (Willie et al., 2017). These hotel properties together provide approximately 447,586 rooms and about 304,000 jobs. In 2015 , the Canadian hotel industry reported around $\$ 18.4$ billion dollars in National Accommodation Revenue along with an additional $\$ 17$ billion dollars from value-added services and an additional $\$ 8.1$ billion dollars for all three levels of government (municipal, provincial and federal) including $\$ 3.6$ billion to the federal government (Prud'homme and Raymond, 2016).
The five-star hotel organisations in Canada are assumed to be of the highest quality. However, competition is very high and it is crucial to focus on service quality as a competitive advantage (AlKahtani et al., 2021).

The majority of research endeavours investigating the relationship between service quality and HRM have been conducted in the manufacturing industry and have shown that this relationship varies depending on geographical location, organisational culture and business industry (Pavan and Reddy, 2017; Hennemann, 2019; Bai and Xue, 2020). The need to understand this relationship between service quality and HRM practices within a hospitality context - specifically within the hotel industry in Canada - led to this study's research questions

Several researchers have attempted to identify the relationships between HRM practices, HRM outcomes and service quality; however, a gap exists with respect to identifying which practices shape the relationship between service quality and HRM (Amevor, 2019; Ahmed et al., 2020).

Globally, the management practices of $\mathrm{HR}$ in workplaces in the hotel industry have been reported to have had a negative impact on the performance of five-star hotels with regard to lowered the service quality and competitiveness of five-star hotels (Hewagamaet al., 2019; Tiago, BorgesTiago and Couto, 2020). The Canadian hotel industry is one of the fastest-growing sectors in the Canadian economy, and thus HRM practices in the workplace are significant in terms of sustaining the industry's success (Wu, Wang and Ling, 2021). Taking into account the status of HRM practices in the workplace, it was found that there is a need for more effective compensation for employees (Sun et al., 2019) such as pay, training, employment security, status recognition, allowances and many other practices that determine the effectiveness of an employment relationship in work environments. According to Lin et al., (2021), compensation refers to financial rewards, tangible services and benefits workers receive as an outcome of their employment relationship. For this reason, we selected the practice of reward and incentives as one of the HR practices that needs to be investigated in this study and how it could affect the level of service quality. 
In addition, the majority of service quality research considered customer-centred (Bambale and Goni, 2017). These studies mainly focus on investigating the customers' perceptions of the quality of various services. However, our study takes a different approach by considering the employee's point of view of the relationship between HR and service quality. Additionally, we selected three levels of employees (low-level, supervisors, and HR managers) to ensure in-depth and more accurate data is gained. According to Silva andMadushani(2017), perceived quality is different from objective or actual quality: a higher-level abstraction rather than a specific attribute of a product, a global assessment that in some cases resembles attitude, and a judgement usually made within a consumer's evoked set. However, the academic debate around how to conceptualise service quality has not yet been fully resolved. Some researchers evaluate service quality based on the disconfirmation paradigm - that is, as a gap between the expected (desired) service and perceived service (Inoyatova, 2019).

Despite the fact that the hospitality industry is facing many changes across the globe at a much faster rate than it ever has before, the expectations of guests, employees, stakeholders and organisations associated with the hospitality industry are increasing at a rapid pace. In order to meet these expectations, the hospitality industry is striving to keep up with new management styles, and innovations in technology and operational processes (Mansour, Aziz and Said, 2018).

\section{Theoretical Background Service Quality}

Service quality definitions have differed from one professional researcher to another depending on the nature of the study as well as on individual understanding of the concept. Given this, the ambiguity of the terminology has necessitated further investigations, which aim to examine the concept broadly in a bid to shed light on its unclear perspectives (Ali et al., 2019). To begin with, various studies provide specific approaches that help in understanding the concept of service quality. For instance, in their analysis, Ali et al., (2021) advocated the distinction between the quality concept in either the goods sector or the service sector. They demonstrated that there exist significant differences between concepts depending on the sector or subject of reference. On the one hand, the concept of quality in the service sector corresponds to that of the goods sector in the sense that they both translate into increased profit margins and shares in the market as well as customer satisfaction (Lemy, Goh and Ferry, 2019).

Further, the concept of service quality could also be viewed through the lens of customer perceptions and expectations of services. Primarily, businesses create services with their customers in mind. Given this, they expect that the final form of the service reflects the needs and requirements of their customers (Ogiemwonyi et al., 2020). For this reason, customer expectations and perceptions of the quality of the anticipated service play a significant part in maintenance and evaluation of service quality. While expectations refer to the image that customers anticipate receiving, perceptions are the actual judgements they pass on the service provider's ability. Abbasi-Moghaddam et al., (2019) found that service quality increased with the increase in individual customer perceptions of prices. Afthanorhanet al., (2019) recorded an overwhelming response from clients following increased customer expectations because of the attractive, aesthetic appeal of official hotel websites. Understanding the quality of service as seen through the eyes of the guest is one of the most effective ways of figuring out the concept of service quality.

Service quality refers to the process of evaluating levels of customer satisfaction with the services delivered to them by a particular business or organisation (Ogiemwonyi et al., 2020). Boonlertvanich(2019) defined service quality as the mechanism through which businesses meet and surpass the expectations of their customers. It is noted that different studies conducted on this subject provide varying definitions of service quality. In any case, all these definitions seem to point towards a service provider's struggle or commitment to ensure improved delivery of quality service, the main aim being to guarantee customer satisfaction (Ali et al., 2019). On occasion, the services delivered may not correspond adequately with the customer's requirements and needs. In such instances, Ogiemwonyi et al (2020) opined, service quality is evaluated in terms of how it compares to the expectations of the individual. 


\section{Hr Practices in the Hotel Industry}

First, it is expected that these practices to boost staff attitude and so to achieve service quality are such that the quality of doing such practices represents a useful indicator for increasing the performance by employees. What is more, quality here refers to concentrating on how well these practices are performed (Nieves and Quintana, 2018). Second, the practices are in theory related to the general aim of service quality (Blayney et al., 2015). Third, these practices connect the most common practices in both the literature and organisational practice (Tiwari, Srivastava, and Kumar, 2019; Mat et al., 2017). Certainly, other HR practices might have a role affecting service quality, but in this research they were considered to be of less direct relevance. It is widely agreed that service quality provided to hotel guests is ultimately determined by the quality of the employee, whose job plays an important role in shaping the customer's experience of the service (Betts, 2020). In turn, the quality of the employee is undoubtedly determined by an organisation's approach to the management and development of its workforce. For example, Raina and Kalse (2018) stated that a professional competitive industry endeavouring to deliver high international standards of service deeply depends on the education and training of its HR.

\section{The Relationship Between Hr Practices and Service Quality in Hotels}

Hotels, like other organisations in the service sector, constantly come under intense pressure to ensure customer loyalty in the competitive business environment. To beat this competition, hotels must put in place correct mechanisms that enable them to acquire new customers while striving to retain the old ones (Islam et al., 2021). Ultimately, such initiatives provide for the formulation of better hotel practices, improved service design and the delivery of superior services. Essentially, through its HR department, an organisation plays a central role in improving the quality of services it offers, which ultimately influences both its customers' and employees' levels of satisfaction (Wang et al., 2016). According to Ross (2017), HR is the lifeline of the service industry. The industry depends on discipline to provide grounds for the development of raw talent into the eventual product, which helps deliver quality service. While one may argue that employees are directly responsible for the provision of quality service in a hotel, it is also true that the performance depends on motivation, satisfaction and training provided by the HR that drives them to worker harder. For this reason, the present study suggests that HR practices are a significant determinant of service quality. Its contribution towards ensuring a high quality of service delivery in the hotel industry cannot be underestimated.

\section{Employee Selection In the Hotel Industry}

According to Jonah et al. (2019), employee resourcing aims to guarantee that the company acquires and keeps the individuals it wants and hires them effectively. The employee resourcing approach is involved in both the formulation and the implementation of organisational strategies. Baum (2016) investigated the challenges in employee supply in the hotel industry and he argued that hotels hang on to their high guest-staff ratio while simultaneously facing difficulties from a shortage of labour supply without being interested in increasing compensation. This issue could be a barrier to selection of qualified employees in the hotel industry. The selection of the best employees is a vital stage in achieving service quality in a hotel. Recruiting and selecting the right worker, who is customer oriented and a creative thinker and who can do the type of work required by the service quality philosophy, can assist in meeting that objective. As stated earlier, $H R$ is primarily about linking $H R$ to the strategic and operational requirements of the business. Su et al. (2016) supported this idea, asserting that good service is obtained when the types of employees a company actually appoints and the types of employees that customers desire to have serving them are matched. They further examined the match between employee and organisation. They discussed how the selection method is one of the most significant parts of HR, basically because it is not feasible to enhance the effectiveness of HR by any means if there is no satisfactory link. Without the necessary link between the employees and the organisation, it is difficult to attain a good return on any of the other investments in HR practices (Rahman et al., 2017). They also mentioned that in the past recruitment and selection have been predominantly concerned with allocating workers to particular jobs. 
Training and Development in the Hotel Industry The environment of the hotel business depends hugely on the face-to-face delivery of service to customers by workers. As Lu et al. (2015) stated, these communications take place several times each day during the customers' stay, and are intentionally or unintentionally assessed by customers against their expectations. Therefore, it becomes crucial that each worker in a hotel is completely equipped to provide excellent service to the guests (Lin et al., 2017). One technique for attaining this aim is through training and development. According to Dhar (2015), training is conducted to achieve a range of outcomes from educating, inspiring and rewarding to improving performance. Dhar added that to recognise the role of training, it is crucial to consider the training function in a logical manner. The training role is a processing system, transforming training requirement data, training expertise, training technology and untrained workers into an output of trained workers for diverse operational tasks. The role of training in enhancing labour standards becomes more vital when service quality is introduced to a hotel. Although training is crucial when pursuing service quality, training can cost a large amount of money and time. Ushakov et al., (2021) exposed how service sectors lagged behind other industries in their commitment to offering training to support quality management. Redman and Mathews added that even when training is employed, it is limited to middle-manager level, while lower-level workers are often ignored. Belias, Vasiliadis, and Mantas (2020) added that the nature of training has also been criticised. Training in Europe has been seen to tend to focus on tools and techniques, while in North America training focuses more on soft skills such as teamwork, communication skills and problem-solving. In this study, training practice will be examined in depth to confirm how Canadian five-star hotels provide their training and how the training could affect the quality of service.

\section{Rewards and Incentives}

According to Sobaih and Hasanein (2020), reward management is about how employees are compensated in accordance with their importance to a business. It involves both monetary and nonmonetary rewards, which form the total reward system (Silvia, 2017). The monetary rewards include both variable and fixed remuneration and employee benefits, while non-monetary rewards include recognition, honour, success and personal growth. Ashton (2018) argued that the hotel and tourism industry offers a poorer level of benefits compared to other industries. Sobaih and Hasanein (2020) expanded on this, providing several contributing issues. These are the large number of small hotels, variations in the level of hotel activity, cost pressures caused by rivalry, and vulnerability of workers, due to contractual status. It can be argued that these factors can be found in Canadian hotels. It can also be argued that low-level workers in Canadian hotels receive poor remuneration compared to other industries. Debating the reward system from a service quality perspective involves concentrating not so much on how a reward system could be settled as on the significance of this concern in sustaining the service quality. Rewards show workers that their efforts to achieve quality, their proficiencies and their judgement are important. Riemer et al. (2018) discussed the consequence of rewards in the effective employment of quality management by focusing on the schemes of these $\mathrm{HR}$ practices. Additionally, recognition has the same significant role in increasing employee satisfaction. Recognition could range from a simple verbal message to modest awards. Ashraf and Bandiera (2018) added that some examples of recognition could be acknowledgement of efforts made by employees in a meeting, or provision of certificates, or vouchers or trips to tourist destinations. Gogia and Soni (2017) recommended some tips for an effective reward system in hotels. They suggested that management should design the reward system in terms of aims, practices and potential incidents. The hotel must also communicate the details of the reward system for all workers to be aware, in order to evade concerns of unfair treatment. Furthermore, information should be kept and made available for reference about the delivery of specific types of incentives among workers. A successful reward system requires that an employee's performance be sensibly compared to that of other employees doing similar tasks as a basis for determining levels of rewards. Finally, leaders should be trained in the skills of incentive evaluation as part of service quality management training programmes, and information on the reward system should be continuously clarified to new workers during their orientation in hotels. 


\section{Internal Career Opportunities}

Brien, Thomas, and Brown (2017) noted that internal career opportunities form one of the areas that HR underperforms in. Naturally, employees feel a sense of motivation when their employer shows interest in their individual growth and development in relation to their career path. Cassel, Thulemark, and Duncan (2018) suggested that employers should actively engage in development of their employees by providing opportunities that enable them to meet their career goals while achieving those of the organisation's at the same time. As an essential HR practice, making internal career opportunities available to employees helps build their confidence in the future. Confidence enables them to commit to the organisation, thereby guaranteeing the provision of quality service. Within $\mathrm{HR}$, the management of the employees and their careers can be explored from different perspectives. One can look at it from a selection and recruitment perspective, a motivation perspective, a training and development perspective or a promotion perspective. If one looks at it from the promotion perspective, one may then consider Pfeifer (2010), who studied a large German limited company that develops and produces innovative products for the global market. Pfeifer's work was carried out in order to study and conduct analysis of the determinants of promotions with the help of efficient allocation of employees and the tournament theory. These approaches have been used in a number of different studies that try to find out why HR decides to promote employees internally. The tournament theory is present in an organisation where several employees compete with each other to get promotion, which would be a step up in the job hierarchy. In such cases, the person who gets the job is the winner and the prize is the upgraded wage (Pfeifer, 2010). The person who is promoted is not promoted on the basis of his/her performance level but on the basis of his/her performance level relative to the performance of the other employees so that others are given an incentive to perform better. One approach that can be used to promote workers is the allocation of resources, because that is not based on performance but is a measure of meeting the needs of the organisation in terms of employees. What this means is that there will be no competition between employees but if there is a need to promote an employee, that decesion will be based on the job antecedents of the given position (Almirall et al., 2014).
In view of the need for the research and the gaps in knowledge that have been identified, a primary study question was established:

What is the impact of HR practicesonservice quality in Canadian hotels?

This study presents an overall approach for exploring the relationship between HR practices and service quality using empirical data from five-star Canadian hotels. In order to achieve this aim, three objectives have been highlighted:

\section{Objective 1}

Identify the HR practices that improve or impede service quality from the hotel staff's perspective.

\section{Objective 2}

Identify the relationship between HR practices and service quality in hotels.

\section{Objective 3}

Develop a conceptual model that describes the relationship between HR practices and service quality for hoteliers.

The conceptual framework argues that using proper HR practices would achieve value for organisations in terms of service quality (figure 1). We argue that hotel staff behaviour in delivering high service quality results from using sound HR practices and will consequently ensure customer satisfaction.

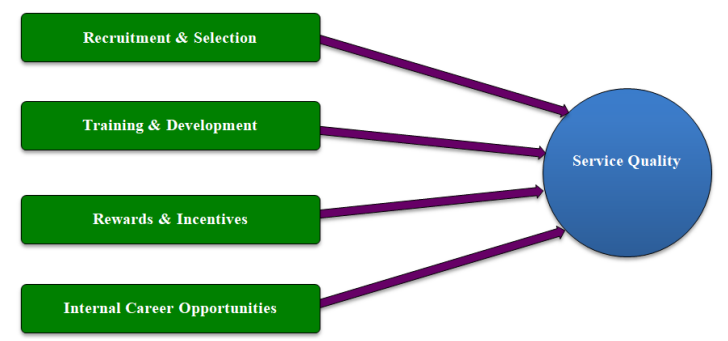

Fig. 1: Research conceptual framework

Based on the existing literature on HR practices, and the main conceptual models of HR and service quality (e.g.,Nunkoo et al., 2021; Alom, Patwary, and Khan, 2019; Sobaih, 2018), the proposed model (see figure 1) provides an integrated framework that can shed light on which system of HR practices impacts on service quality. Given the main aim of the study, which focuses on the relationship 
between HR practices and service quality, this model provides a framework for understanding the potential performance implications of HR practices and how they affect the level of service quality. The above model proposes that the perceived system of HR practices positively influences the level of employees' performance, which in turn positively affects the level of service quality.

\section{Method}

\section{Sample and Procedures}

In the current study, we adopted the philosophy of interpretivism as its epistemological perspective; since it involves mainly qualitative data collected at different stages of the research to answer the research question and to achieve its aim and objectives. In this study, we used the qualitative approach as a methodological strategy to answer the research question and achieve its aim and objectives. For this study, we designed sets of interviews in order to get the perspective on relationship between HR practices and service quality from top to bottom within hotel organisations in Canada. They were semi-structured and face-toface and comprised of three sets of interviewees (6 HR Managers; 6 supervisors; 22 non-manager staff). We selected hotels with their similar characteristics to get a uniform sample profile data. However, qualitative research findings can be tentatively generalised to similar contexts only. All the three sets of interviews had the same contentto enable the observation of how HR managers, supervisors and non-manager staff agree or disagree in their perceptions of HR practices and service quality concept. The data for the study was obtained during interviews by notes writing and audio-recording. Besides, during the interviews, field notes were taken and at the same time the nonverbal behaviour of the interviewees was observed. We stored the recordings electronically and the NVIVO 10 software enabled usto collect, organise and analyse the unstructured aspects of the data.

The interviewees of the study were employees of 5-star hotels in Canada only, and more particularly from the British Colombia province as it is one of the most tourist attraction areas in Canada. In addition, the hotels are chain hotels, thus all of them following the same standards across Canada. Although interviewees acknowledged and agreed to the study results being published, we agreed to not disclose identifiable information that would directly denote the exact locations of the interviewees' organisations as per the confidentiality statement.

The hotels' sizeswere similar - ranging from 365 rooms to 413 rooms (343-401 full-time and 89-114 part-time employees) and located in Vancouver, Richmond, Burnaby, and Victoria. We contacted 15 five-star hotels. 6 of which accepted. The duration of interviews was between 60 to 90 minutes. We selected interviewees using purposeful sampling within the selected hotels of Canada.

Table 1: An overview of the investigated hotels

\begin{tabular}{lccccc}
\hline Hotel & Location & $\begin{array}{c}\text { Type of Hotel } \\
\text { of Rooms }\end{array}$ & $\begin{array}{c}\text { Size I } \\
\text { No. }\end{array}$ & $\begin{array}{c}\text { No. of Full- } \\
\text { Time Employees }\end{array}$ & $\begin{array}{c}\text { No. of Part- } \\
\text { Time Employees }\end{array}$ \\
\hline Hotel 1 & British Columbia, Vancouver City & Business Hotel & 376 & 370 & 100 \\
Hotel 2 & British Columbia, Vancouver City & Business Hotel & 402 & 398 & 111 \\
Hotel 3 & British Columbia, Richmond City & Resort Hotel & 413 & 359 & 114 \\
Hotel 4 & British Columbia, Richmond City & Business Hotel & 390 & 401 & 106 \\
Hotel 5 & British Columbia, Burnaby City & Business Hotel & 367 & 351 & 98 \\
Hotel 6 & British Columbia, Victoria City & Resort Hotel & 365 & 343 & 89 \\
\hline
\end{tabular}

\section{An Overview of the Selected Hotels}

Firstly, it was important for us to gain a good understanding of the hotels. As the research is deductive, any information gained from the field was potentially crucial to the study from day one (de Vet and Wauters, 2018). Secondly, this study aims to gain a broad view of service quality concept and its dimensions from a managerial, supervisor, and line staff approach utilising the multiple perspectives of participants (McKibben et al., 2020). Table 1 offers an overview of these hotels. We have not revealed the name of hotels and their specific addresses for 


$$
\text { Vol. 03(1-2) 74-91 (2021) }
$$

the purpose of confidentiality; however, the hotels' sizes were similar. We selected these hotels as they are the most famous hotels in Canada and they have clear HR standards.

\section{Identifying Themes}

The world according to McKibben et al., (2020) is something messy, and he himself is interested in the mess politics, the process of knowing mess and methodologies for knowing mess. He suggested simplicity will not guide us to recognise this mess but rather, in practice, research needs to be messy and diverse. Consequently, to enable the identification and extraction of relevant data from this messy social environment, it has been necessary for us to adopt a qualitative study research. Every piece of information gathered from the selected hotels was potentially crucial data and had to be included and considered.

\section{Using Thematic Analysis}

According to Belotto (2018) thematic analysis is a method for identifying, analysing and reporting patterns or themes within data. We chose thematic to represent this as research themes can be identified from the collected data. Additionally, it is proposed that by using this method, the data can be analysed without being simplified; allowing the underlying complexity to remain accessible.
\end{abstract}

As Vaismoradi and Snelgrove (2019), we followed six phases when using thematic analysis as it appears in Table 2.

Table 2: Thematic analysis phases

\begin{tabular}{lll}
\hline \multicolumn{2}{l}{ Phase } & Descriptionof the process \\
\hline $1 \quad \begin{array}{l}\text { Familiarising yourself with } \\
\text { your data }\end{array} \quad \begin{array}{l}\text { Generating initial codes } \\
\text { Transcribing data (if necessary), reading and rereading the } \\
\text { data, noting down initial ideas. } \\
\text { Coding interesting features of the data in a systematic fashion } \\
\text { across the entire data set, collating data relevant to each code. } \\
\text { Collating codes into potential themes, gathering all data relevant } \\
\text { to each potential theme. } \\
\text { Checking if the themes work in relation to the coded extracts } \\
\text { (phase 1) and the entire data set (phase 2), generating a } \\
\text { thematic 'map' of the analysis. } \\
\text { On-going analysis to refine the specifics of each theme, and the } \\
\text { overall story the analysis tells, generating clear definitions and } \\
\text { names for each theme. } \\
\text { nefining and naming themes }\end{array}$ & $\begin{array}{l}\text { The final opportunity for analysis. Selection of vivid compelling } \\
\text { extract examples, final analysis of selected extracts, relating back } \\
\text { of the analysis to the research question and literature, producing } \\
\text { a scholarly report of the analysis. }\end{array}$ \\
\hline
\end{tabular}

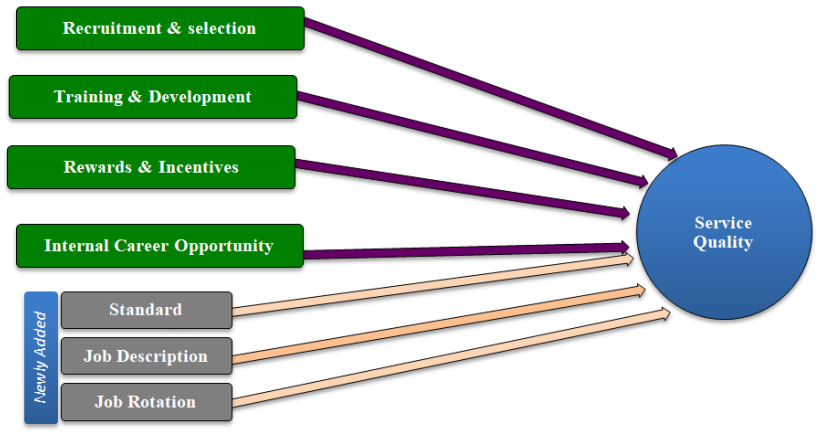

Source: developed by the authors

Fig. 2: The final conceptual model 


\section{Results}

Comparing to the primary conceptual framework (see figure 1), the collected data resulted in amending the primary conceptual framework by adding three more themes. These new themes are standards, job description and job rotation as appears in figure 2 .

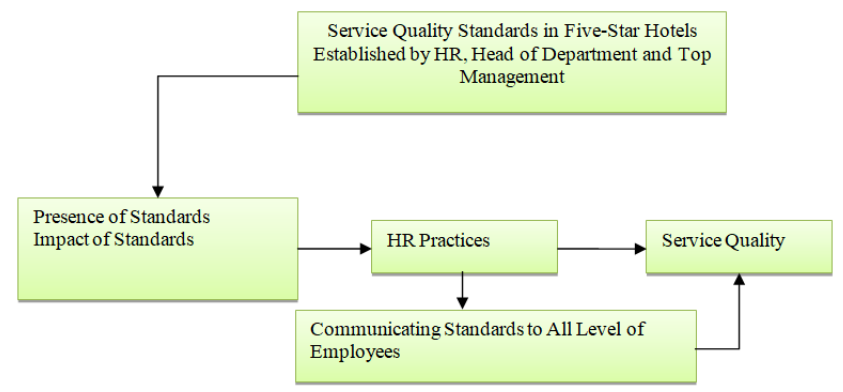

Fig. 3: The relationship between standards, HR practices and service quality

\section{The Role of Standards for Improving Service Quality}

Understanding standards followed for applying service quality helps in illustrating the relationship between HR practices and service quality. Figure 3 was derived from the managers'viewpoints with regard to the relationship between standards followed for applying service quality, HR practices, and service quality.

Figure 3 illustrates how specific service standards followed by employees can act as links between the HR practices and service quality. These standards are generally established by each department of the hotel separately after the approval of the top management. However, in hotel organisations, where HR is an important department, the standards are established mutually by top management, heads of departments and HR leaders. The communication of service quality standards plays a significant role here - and it should do so at all hierarchical levels. Hence, HR leaders need to collaborate with top management and heads of departments to communicate service quality standards to all levels of employees throughout the five-star hotel organisation. It was also revealed that improving the communication of service quality standards among employees at all hierarchical levels positively affectsservice quality.

Relationship between the Job Description and the Service Quality

Job description plays the key role in understanding whether there is an actual gap in role clarity or lack of motivation which is ultimately causing the lack of service quality behaviour. Lack of job clarity is itself one of the demotivating factors. However, some employees tend to perform high standards of service either because of lack of job clarity or purely because of lack of intention and motivation. In addition, it is implied that lack of job description can negatively influencethe HR practices outcomes, from recruitment and selection to promotion systems due to employees not getting the clarity regarding what is expected of them and what are basically their job responsibilities. Most of the hotel organisations do not provide the written job description to their employees as they are informed verbally regarding their responsibilities and daily tasks. This causes lack of clarity among employees regarding their positions, and it also causes resentment among employees when they are assigned to additional duties. This can ultimately jeopardise any other $\mathrm{HR}$ practices and service quality issue. This is also one of the reasons which led us to include the job description question in the interviews in order to investigate the mediating impact of job description on HR practices and service quality. HR needs to provide formal job descriptions listing basic job responsibilities and additional roles and duties in order to make a positive impact on the service quality behaviour of employees. HR also needs to provide clear understanding the roles and duties of employees. The revised model implies that clear job descriptions have a positive impact on both HR practices and service quality. 


$$
\text { Vol. 03(1-2) 74-91 (2021) }
$$

\section{Relationship between Job Rotation and Service Quality}

The purpose here was to assess how three groups of employees described the job rotation in their hotels and how it positively or negatively affected the delivery of service quality. Job rotation is generally practised at non-manager employee level in the hotel industry. It is implied that proper shift management could have a positive mediating impact on HR practices and service quality. However, if employees are rotated without their willingness to be so, then job rotation would have a negative impact on other $\mathrm{HR}$ practices and ultimately on the service quality.

Only few interviewees (HR1, HR3, FO2, W2) indicated that job rotation was practiced in their hotels and that is also particularly in some departments. The HR managers indicated that there was some form of job rotation even though it was not as what it was imagined as being. For example, the hotel ensures that the HR administrators are rotated in order to ensure that they have experiences in dealing with various HR issues. However, rotation between departments, like a member of the HR Admin staff being asked to work as a cook or a waiter does not happen. The non-manager employees indicated that job rotation in their five-star hotels was done to some extent because their hotel believes in providing quality services and each staff member is expected to be the best in his job. They indicated that their duties are rotated so that they could deliver their best services. For instance, sometimes, an employee's duty of greeting the guestswas changed to making bookings on phone calls. This change is positive as employees get to learn new things.

However, the majority of interviewees indicated that job rotation was not practiced in their hotels (HR3, R2, FOS1, and FOS2). They also spoke mostly negatively, or at best, in neutralterms, about job rotation; thereby suggesting that job rotation would not affect the service quality. Some HR managers indicted that they did not practice job rotation at their hotels, neither did they really advocate it, for they claimed that in their hotels it was just not possible to rotate the employees without such a practice having a negative impact on service quality. For example, imagine having a waiter being asked to work in the HR department. It would not work and would negatively affectservice quality. Some nonmanager employees also shared similarsuch views.
They averred that job rotation was not going to work in their hotel as in a five-star hotels the employees need to be trained on how they can do their own individual specific jobs so that they are able to offer customers high service quality. That requires the use of many resources and much time; and even then, theattainment of high levels of quality service are not guaranteed. Some employees do not even have any interest in being transferred to other departments, neither do they have time to learn theskills, which would allow them to fit into the new department. If employees are forced to rotate, they might quit, or, if they agree to the necessarytraining, may end up providing low quality service. In such circumstances, job rotation would negatively affect service quality as averred by some non- manager employees (R1, R6) while wasting many resources in both time and money. For these reasons, it cannot be practised in their hotels.

Evidence is provided regarding how the study has addressed each objective - this is detailed as follows:

\section{Objective 1}

Identify the HR practices that improve or impede service quality from the hotel staff's perspective.

The findings of this study indicated that there is a strong relationship between recruitment and selection and service quality. The themes obtained from interviewees suggested that an established process from hiring to induction of new employees was an effective first step in ensuring that new people joining the organisation were aware of the service quality standards and expectations. The findings further indicated that recruitment and selection help in the hiring and selection of skilled people to deliver service quality. This suggested that recruitment and selection as an HR practice play a key role in service quality. This is in fact the first step in ensuring that employees are able to understand the expectations of service quality for five-star hotels in Canada. The findings of this study also indicated that there is a strong relationship between training and service quality. The themes obtained from interviewees suggested that employees are generally provided with on-the-job skills training at all levels. This training will eventually help them to acquire various skills to achieve the desired service quality outcomes. The findings of this study are 
consistent with previous studies in the available literature. Training and on-the-job mentoring at Accor Hotel Group and Hilton Corporation were the heart of the knowledge sharing and creation policies adopted by these establishments in developing professional competences and effective teams (Alom, Patwary, and Khan, 2019). Training is an important HR practice for creating a business environment for high organisational performance: "Training positively impacts employee productivity, results in higher levels of employee satisfaction, increases an employee's ability to perform tasks, and increases knowledge transfer among employees" (HR6). It is clear that dedicated time for workplace learning and job-related training is required for high organisational performance.

Furthermore, the findings of this study indicated that there is a strong relationship between rewards and incentives and service quality outcomes. The themes obtained from interviewees suggested that incentives and rewards motivate employees to perform to high standards of service quality. In addition, both monetary and non-monetary incentives and rewards are given to enhance job satisfaction and employee motivation. The findings of this study are consistent with previous studies in the available literature (Ashton, 2018; Silvia, 2017). Moreover, this study indicated that internal career opportunities are not a strong determinant of service quality in the hotel industry of Canada. The themes obtained from interviewees suggested that both external and internal hiring is done but preference is given to one or the other according to the expediency of the moment. In addition, while promotions are based on both performance and non-performance reviews within the same department, the same is not available for internal career opportunities in terms of employees moving from one department to another. This is further validated by employees not being rotated in their jobs. This relationship coincides with Tiwari, Srivastava, and Kumar (2019), as career opportunities might have an effect on ensuring quality of service.

\section{Objective 2}

Identify the relationship between HR practices and service quality in hotels.

Various factors contribute to the effectiveness of $\mathrm{HR}$ and influence service quality in multinational hotels in Canada. Based on a review of a significant volume of literature focusing on HR worldwide and in Canada, the main issue of "multinational hotel HR practices" can be divided into the following categories: "recruitment and selection, training and development, and rewards, incentives, and internal career opportunities". Although these issues have been mentioned several times at all levels of the literature review (global, Asia and Canada), few of the studies have focused on multinational hotels. None of these issues has been tested at the multinational hotel level. Thus, the present study fills some of the gaps in the literature.

Recruitment and selection of the qualified and skilled employees in the Canadian hotels were the first practices that proved to have a direct link to service quality. This coincides with Zhang (2017) as they averred that recruitment and selection practices influence service quality.

The shortage of qualified employees creates a need for high-quality training programmes in various organisations, especially multinational hotels, which need higher-quality employees to meet the international standard. People in Canada favour employment in companies with adequate and advanced training and development programmes, which may offer them better career development opportunities (Ali et al., 2021). Controversially, companies may regard training as a waste of time and/or money. Some small hotels may not have enough capital to support their training. However, in terms of companies, training may increase working efficiency among employees and maintain high service quality. As previously discussed, service quality is one of the key factors in maintaining the competitive advantage of this people-oriented industry (Nieves and Quintana, 2018). Therefore, hotel companies must offer sufficient and proper training programmes because through training sessions employees may better fit into their positions, reduce the cultural gap, and become fully involved in Western-style multinational corporate cultures.

In addition to benefits and compensation, development opportunities are other major factors that may affect the turnover rate. Brands should offer sufficient orientation and on-the-job training 
to help newcomers better adapt to the position and brand culture.

Recreational training, such as yoga and flower arranging, might bring more fun and a learning atmosphere to daily work. Another key strategy to retain qualified employees is to offer adequate development opportunities, such as cross-training in other properties or study in universities overseas. Mat et al., (2017) stated that formal leadership programmes, as well as on-the-job learning opportunities, have become important in attracting and retaining talent in Canada. Finally, only two of the managers interviewed claimed they have career plans for every new employee. For instance " we always keep in mind that every employee needs to have career plan in place" HR3 and HR 5 said " career plans exist for all workers ...". However, creating a clear career plan is an effective way to help employees become motivated. They may stay to grow with the company if they can clearly see their career paths. Betts (2020) contended that companies should build talent for long-term considerations instead of buying it for the short term. The findings of this study are also consistent with these findings.

The findings of this study indicated that rewards, incentives and internal career opportunities are important factors for influencing service quality. This also includes turnover and rotation. The findings of this study revealed that positive turnover, which means internal transfer, is positive for a company's operation. However, negative turnover affects the turnover rate, increases hotels' recruitment and training costs, and decreases productivity when co-workers leave. Therefore, negative turnover is discussed in the following sections.

Because the products that hotels offer to their customers are intangible services, employees who offer quality service directly can contribute to the advantage of their hotels (Raina and Kalse, 2018). However, graduates (who might provide quality service) want rapid growth and may feel underestimated by their supervisors. They have claimed that they do not have opportunities for managerial roles (Belias, Vasiliadis, and Mantas, 2020). Compared with other industries, the hotel industry has been listed as one of the lowestcompensation industries and cannot offer its employees competitive compensation and benefit packages (Cassel, Thulemark, and Duncan, 2018). At the same time, hotel professionals who have a strong knowledge of English and management skills are quite popular with banks and other organisations. Furthermore, a lack of employee culture may be a potential factor motivating employees to leave the company for even a small increase in salary or elevation of position (Katou, 2016). As a result, high turnover may be the common issue that reduces productivity and the morale of other employees.

The hotel industry has been regarded as a low-income and high-workload service industry (Khuong, Mai, and Phuong, 2020). Therefore, fewer graduates enter the industry, thus aggravating the current situation. Presently, the most important step that five-star hotel management should consider is repositioning the industry and rebuilding the industry's image, especially among the younger generation. Hotel professionals could make industry presentations in high schools, letting students know the reality of the hotel industry. Young people should know that there are a lot of opportunities in the hotel industry as it is among the fastest-growing industries in Canada. Talented people in the industry can move up much more quickly than in other industries. Hotels could offer talented employees opportunities for further study in universities overseas. Hotel professionals should try their best to establish a prestigious image of the hotel industry among young people. Therefore, when members of this new generation enter the industry, they will not be disappointed and leave immediately.

\section{Objective 3}

Develop a conceptual model that describes the relationship between HR practices and service quality for hoteliers.

Phase one identified the initial model based on the literature review and the hotels' senior staff's perceptions of the initial conceptual model (figure 1). The initial model was developed from and composed of specific HR practices that have an effect on service quality. The model will help managers to manage service quality on the basis of realising the different service quality measures and the importance of integrating customers' needs and expectations. 
Phase two confirmed and modified the initial model in the light of the comments and feedback gained from the selected hotel staff. The result was a revised model (see figure 2). Some new themes (such as standards, job descriptions and job rotation) were merged and all of them demonstrated the relationship between HR practices and service quality for hoteliers.

In light of the previous discussions, it can be claimed that all objectives required to answer the research question in this study have been met.

\section{Implications Theoretical Implications}

Our study stated the need to present the intended HR practices of recruitment, selection, training and development, incentives and rewards, and internal career opportunities, all of which reflect the key practices related to service quality in the Canadian hotel industry. However, it was found that much uncertainty exists surrounding the concept of service quality in the hotel industry: its determinants, debates, and the relationship between HR practices and service quality. In particular, the literature was synthesised to reveal the importance of considering the qualitative approach in order to obtain a better understanding of the relationship between HR practices and service quality in hotels. The study explored the meaning and the value of service quality among hotel staff and to get to know the opinions of hotel seniors about the initial model constructs. The service quality dimensions that were identified and examined in this study have coincided with the current and relevant review of the literature. As a result, service quality has been defined as the manner in which employees use the available resources or information to provide a valuable result according to customer needs and expectations. Then the main determinants of service quality were developed and confirmed the multidimensional nature of service quality in the hotel sector in general and the difficulty of evaluating service quality in hotel operations.

Recruitment and selection of the qualified and skilled employees in the Canadian hotels were the first practices that proved to have a direct link to service quality. This coincides with Nieves and Quintana (2018) as they averred that recruitment and selection practices influence service quality.
The shortage of qualified employees creates a need for concentrating on training programmes in various departments in order to meet the international standard. Controversially, companies may regard training as a waste of time and/or money. Some hotels may not have enough capital to support their training. However, in terms of companies, training may increase working efficiency among employees and maintain high service quality. The hotel industry has been observed as a low-pay and high-workload service industry (Baum, 2016). Therefore, fewer graduates enter the industry, thus aggravating the current situation. Presently, the most important step that five-star hotel management should consider is repositioning the industry and rebuilding the industry's image, especially among the younger generation. Hotel professionals could make industry presentations in high schools, letting students know the reality of the hotel industry. Young people should know that there are many opportunities in the hotel industry as it is among the fastest-growing industries in Canada. Talented people in the industry can move up much more quickly than in other industries. In this study, we found that there is a positive relationship between HR practices as a bundle (recruitment and selection, training and development, rewards and incentives, and internal career opportunities) and between the levels of service quality. Interestingly, many interviewees highlighted the role of job standard, job rotation and job description in improving the service quality. These practices were added later to the conceptual model (figure 1) and the final revised model was created (see figure 2).

Based on the findings of the study, it has been possible to refine what is meant by service quality and in doing so move towards a more accurate working definition as developed through this study and thus make another contribution to theory and literature in terms of the manner in which employees use the available resources or information in order to provide a valuable result according to customer needs and expectations. This service quality definition highlights the multidimensional nature of service quality and therefore provides a novel contribution to knowledge. Our study evidenced a conceptual model (figure 2) acting as a value stream mapping of specific HR practices and their effect on delivering high service quality. The current study model contributes to professionals understanding 
and knowledge of the causal relationship between HR practices and service quality.

\section{Practical Implications}

The findings of the current study provide interesting and practical managerial implications for the hotel sector in general and for Canadian five-star hotels in particular - as investigated in this particular study. It is concluded that the final model we developed could be used not only for ensuring service quality but also for improving and managing HR practices. In the case of service quality decline, we found that the substantial impact of some HR practices could help improve service quality. The study holds several practical implications for hotel industry. First, a hotel could select workforces based on job-related characteristics, i.e. personality and job knowledge, resulting in the consistency of service quality. Thus, workers have a satisfactory understanding and uphold uniformity of service quality when communicating with customers. Second, employee perceptions of "training \& development" and "compensation \& benefits" will impact the perception of responsiveness of customers through service actions. Therefore, if hotels can provide workers with customer service courses and offer incentive rewards programmes, then the more likely workers tend to be supporting clients and assisting guests with issues beyond what is anticipated or needed. Third, in managerial HR practices, offering training and development activities to hotel employee is valuable and forms employee' service behaviour. Hotels must pay particular attention to a systematic needs assessment, and rigorous assessment. In addition, if workers can expect their efforts to be properly rewarded, they are more likely to satisfy different customers' needs. Finally, if workers were hired through sophisticated recruitment and selection procedures planned to screen out all but the very best prospective candidates, then the attention that the workers provided to their guests would be encouraged through the service behaviour. In a hotel service setting, superiors can inform candidates about the special service culture in hotel industry by recruiting and selecting, to appoint employees for the hotel, rather than for a certain job. Then workers might make greater effort to recognise customers need thereby improving customers' perceptions of the "empathy" dimension of service.In addition, the findings of study provide solid reference data for hotel managers to reduce many employee-related costs by measuring their productivity and matching an employee's salary with effort.

Understanding this relationship is very important for several reasons. First, by understanding the relationships between HR practices and service quality, managers may better improve service quality and therefore enhance the competitiveness. Second, understanding the relationship between HR practices and HR outcomes may contribute to the development of HR practices aimed at retaining competent employees and developing the employee capabilities required for high service quality. Third, by understanding the relationship between HR outcomes and service quality, managers can better attain HR outcomes such as highly competent employees, employees committed to learning, and higher levels of job satisfaction, thus achieving higher levels of productivity and in turn effectively meeting organisational objectives.

\section{Limitations and Direction for Future Research}

A major limitation concerned the qualitative study research design. The data collected for the proposed study may limit the generalisation. Consequently, the findings might not be applicable to other international hotel destinations or other hospitality organisations. However, generalisation of the findings from the current descriptive-qualitative study is not a concern due to the limited number of empirical studies and the need to gain an in-depth understanding of the link between HR practices and service quality. Further research may include some control and context variables (e.g., hotel ownership type, position level, gender) that were not included in this investigation. In this study, through a cross-sectional survey in the last phase, a number of models were tested. However, a longitudinal study is required to further explore the temporal dynamics of the resulting models. Also, in the future it is recommended to use mixed method (quantitative and qualitative) in order to come up with more generalisable results.

Another limitation is related to the predetermined HR practices investigated in this study, which are recruitment and selection; training and development; rewards and incentives; and internal career opportunities. It may be useful to select more practices or different ones to investigate the 
relationship with service quality. Future work on HR practices should include validating these practices with other individual HR constructs such as HR planning, job analysis and job evaluation.

\section{Acknowledgement}

We would like to thank all HR managers who supported us in completing this paper. We would also like to thank all of the individuals who participated in this study for their time and insights. We are grateful for the companies that allowed us to communicate with their workers.

\section{Funding}

No fund was used from external source. Only personal fund was used.

\section{Conflict of Interest}

No conflict of interest was found.

\section{References}

1. Abbasi-Moghaddam, M. A., Zarei, E., Bagherzadeh, R., Dargahi, H., \&Farrokhi, P. (2019).Evaluation of service quality from patients' viewpoint. BMC Health Services Research, 19(1), 1-7.

2. Abdul, M. O. H. A. N. I., Rahman, M. M., ALla, N. A., Dato'Mansor, Z. U. R. A. I. N. A., Uddin, M. J., \& Saidur, M. (2018). The Nexus between job satisfactions and human resource management (HRM) practices: A perceptual analysis of commercial banks in Bangladesh. International Journal of Economics and Management, 12(S2), pp.377-386.

3. Afthanorhan, A., Awang, Z., Rashid, N., Foziah, H., \&Ghazali, P. (2019).Assessing the effects of service quality on customer satisfaction. Management Science Letters, 9(1), 13-24.

4. Ahmed, A., Naseer, R., Asadullah, M., \& Khan, H. (2020). Managing Service Quality, Food Quality, Price Fairness and Customer Retention: A Holistic Perspective. Annals of Contemporary Developments in Management \& HR (ACDMHR), Print ISSN, 2632-7686.

5. Ali, B. J., Gardi, B., Jabbar Othman, B., Ali Ahmed, S., Burhan Ismael, N., AbdallaHamza, P., ...\& Anwar, G. (2021). Hotel Service Quality: The Impact of Service Quality on Customer Satisfaction in Hospitality. Ali, BJ, Gardi, B., Othman, BJ, Ahmed, SA, Ismael, NB, Hamza, PA, Aziz, HM, Sabir, BY, Anwar, G.(2021). Hotel Service Quality: The Impact of Service Quality on Customer Satisfaction in Hospitality. International Journal of Engineering, Business and Management, 5(3), 14-28.

6. Ali, M. H., Bashir, M. A., Rahman, M. M., Wai, L. M., Rahman, M. A., \& Hamid, A. B. A. (2019). Relationships between Service
Quality, Customer Experience and Customer Satisfaction of E-Banking In Bangladesh. Journal of Advanced Research in Business and Management Studies, 15(1), pp. 23-32.

7. AlKahtani, N., Iqbal, S., Sohail, M., Sheraz, F., Jahan, S., Anwar, B., \&Haider, S. (2021). Impact of employee empowerment on organizational commitment through job satisfaction in four and five stars hotel industry. Management Science Letters, 11(3), 813-822.

8. Almirall, E., Lee, M. and Majchrzak, A. (2014). Open innovation requires integrated competition-community ecosystems: Lessons learned from civic open innovation. Business Horizons, 57(3), pp.391-400.

9. Alom, S., Patwary, A. K., \& Khan, M. M. H. (2019). Factors affecting the turnover intention of Bangladeshi migrants in the United Arab Emirates: An empirical study on the hotel industry. International Journal of Innovation, Creativity and Change, 8(3), 344-360.

10. Al-Refaie, A. (2015). Effects of human resource management on hotel performance using structural equation modeling. Computers in Human Behavior, 43, pp.293-303.

11. Amevor, W. M. (2019). Translating HR Training into Quality Service at Management Services Department (Doctoral dissertation, University of Ghana).

12. Ashraf, N. and Bandiera, O., (2018). Social incentives in organizations. Annual Review of Economics, 10, pp.439-463.

13. Ashton, A. S. (2018). How human resources management best practice influence employee satisfaction and job retention in the Thai hotel industry. Journal of Human Resources in Hospitality \& Tourism, 17(2), 175-199. 

Vol. 03(1-2) 74-91 (2021)

14. Bai, Y., Lin, L., \&Xue, H. (2020). Linking HR Practices and HR Service-Quality to Employee Performance: A Regulatory Focus Perspective. In Academy of Management Proceedings (Vol. 2020, No. 1, p. 14662). Briarcliff Manor, NY 10510: Academy of Management.

15. Bambale, A. J., \&Goni, K. (2017). Is Service Quality Going to Integrate Human Resource Management Practices (HRMPS) and Customer Satisfaction in Hotel Industry. International Journal of Innovation, Management and Technology, 8(3), 243-247.

16. Baum, T. (2016). Human resource issues in international tourism. Elsevier.

17. Belias, D., Vasiliadis, L., \& Mantas, C. (2020). The Human Resource Training and Development of Employees Working on Luxurious Hotels in Greece. Cultural and Tourism Innovation in the Digital Era, 639-648.

18. Belotto, M. J. (2018). Data analysis methods for qualitative research: Managing the challenges of coding, interrater reliability, and thematic analysis. Qualitative Report, 23(11).

19. Betts, B. S. H. (2020). The Importance of Human Resource Management in the Hotel industry in Sierra Leone. American Scientific Research Journal for Engineering, Technology, and Sciences (ASRJETS), 64(1), 96-108.

20. Blayney, C., Cormier-MacBurnie, P. and Young, J. D. (2018). "The Devolution of Human Resource Management to Line Managers: A Preliminary Examination of the Hotel Industry in Halifax, Canada", Working paper, Mount Saint Vincent University, Halifax, Nova Scotia.

21. Boonlertvanich, K. (2019). Service quality, satisfaction, trust, and loyalty: the moderating role of main-bank and wealth status. International Journal of Bank Marketing.

22. Brien, A., Thomas, N. J., \& Brown, E. A. (2017). How hotel employee job-identity impacts the hotel industry: The uncomfortable truth. Journal of Hospitality and Tourism Management, 31, 235-243.

23. Cassel, S. H., Thulemark, M., \& Duncan, T. (2018).Career paths and mobility in the Swedish hospitality sector. Tourism Geographies, 20(1), 29-48.

24. de Vet, B., \&Wauters, B. (2018). Follow the leader: testing a deductive approach for studying parliamentary party leadership roles. The Journal of Legislative Studies,
24(3), 359-372.

25. Dhar, R.L. (2015). Service quality and the training of employees: The mediating role of organizational commitment. Tourism Management, 46, pp.419-430.

26. Francis, H., \& Baum, T. (2018). HR transformation within the hotel industry: building capacity for change. Worldwide Hospitality and Tourism Themes.

27. Gogia, S.K. and Soni, M. (2017). Impact of reward management system on organizational performance with special reference to hotel industry in Jaipur: a literature review. Journal of Modern Management and Entrepreneurship, 7(4), pp.115-124.

28. Hennemann, M. (2019). Benefits and challenges of setting up HR Shared Service Centers: An example from a pharma company based in Prague, Czech Republic.

29. Hewagama, G., Boxall, P., Cheung, G., \& Hutchison, A. (2019).Service recovery through empowerment?HRM, employee performance and job satisfaction in hotels. International Journal of Hospitality Management, 81, 73-82.

30. Inoyatova, S. A. (2019). Human resource management practices in hospitality industry in uzbekistan: what are the HR issues, functions and roles?. Economics and Innovative Technologies, 2019(5), 4.

31. Islam, M. A., Hack-Polay, D., Haque, A., Rahman, M., \&Hossain, M. S. (2021).Moderating role of psychological empowerment on the relationship between green HRM practices and millennial employee retention in the hotel industry of Bangladesh. Business Strategy \& Development.

32. Jonah, J.M., Misango, S. and Ombuki, C. (2019). Influence of employee resourcing on organizational performance of devolved governments in South Eastern Kenya region.

33. Katou, A. A. (2016). Human resource management and performance in the hospitality industry: methodological issues. In Project Management: Concepts, Methodologies, Tools, and Applications (pp. 1980-1999). IGI Global.

34. Khuong, M., Mai, T., \& Phuong, N. (2020). The impacts of human resource management practices on employees' motivation and loyalty. Management Science Letters, 10(11), 26732682.

35. Lemy, D., Goh, E., \& Ferry, J. (2019).Moving out of the silo: How service quality innovations can 


$$
\text { Vol. 03(1-2) 74-91 (2021) }
$$

develop customer loyalty in Indonesia's hotels. Journal of Vacation Marketing, 25(4), 462-479.

36. Lin, M., Ling, Q., Liu, Y., \& Hu, R. (2021).The effects of service climate and internal service quality on frontline hotel employees' serviceoriented behaviors. International Journal of Hospitality Management, 97, 102995.

37. Lin, Q., Zhang, L. and Liu, J., (2017). Research on the Present Situation and Countermeasures of the Training of Common Staff in Star Hotels. DEStech Transactions on Social Science, Education and Human Science, (eemt).

38. Lu, C., Berchoux, C., Marek, M. W., and Chen, B. (2015). Service quality and customer satisfaction: qualitative research implications for luxury hotels. International Journal of Culture, Tourism and Hospitality Research, 9(2), pp.168-182.

39. Mansour, H., Aziz, W., \& Said, E. L. (2018). Dimensions of Service Quality for Improvement of Employees Performance: Study in First Class Hotels in Alexandria. International Journal of Heritage, Tourism and Hospitality, 12(2), 141-159.

40. Mat, N. H. N., Yusof, Y., Salleh, H. S., \& Mohamed, W. N. (2017). Employees' understanding of HRM practices in the hotel industry. Advanced Science Letters, 23(11), 10680-10683.

41. McKibben, W. B., Cade, R., Purgason, L. L., \&Wahesh, E. (2020). How to Conduct a Deductive Content Analysis in Counseling Research. Counseling Outcome Research and Evaluation, 1-13.

42. Mokhtar, S., \&Sjahruddin, H. (2019). An examination of the relationships between customer relationship management quality, service quality, customer satisfaction and customer loyalty: The case of five star hotels. Advances in Social Sciences Research Journal, 6(2).

43. Nadda, V., Rahimi, R., Dadwal, S., and Bhan Singh, U. (2014). Impact of HR Practices on Employee's Performance: Case of UK Hotel Industry. Journal of Hospitality and Tourism, 12(2), pp.88-111.

44. Nieves, J., \& Quintana, A. (2018). Human resource practices and innovation in the hotel industry: The mediating role of human capital. Tourism and Hospitality Research, 18(1), 72-83.

45. Nunkoo, R., Teeroovengadum, V., Ringle, C.
M., \&Sunnassee, V. (2020). Service quality and customer satisfaction: The moderating effects of hotel star rating. International Journal of Hospitality Management, 91, 102414.

46. Ogiemwonyi, O., Harun, A., Rahman, A., Hamawandy, N. M., Alam, M. N., \& Jalal, F. B. (2020).Examining the impact of service quality dimensions on customer loyalty towards hypermarket retailing: A case study of Malaysia. International Journal of PsychosocialRehabilitation, 24(04).

47. Pavan, K., \& Reddy, N. T. (2017). HR practices with reference to service quality and pilgrim satisfaction relationship: A case study on TirumalaTirupatidevasthanamannaprasadam refectory. Global Journal of Finance and Management, 1, 1-14.

48. Pfeifer, C. (2010). Determinants of promotions in an internal labour market. Schmalenbach Business Review, 62(4), pp.342-358.

49. Prud'homme, B. and Raymond, L. (2016). Implementation of sustainable development practices in the hospitality industry: A case study of five Canadian hotels. International Journal of Contemporary Hospitality Management, 28(3), pp.609-639.

50. Rahman, M. M., Abdul, M., Ali, N. A., Uddin, M. J., \& Rahman, M. S. (2017). Employees' Retention Strategy on Quality of Work Life (QWL) Dimensions of Private Commercial Banks in Bangladesh. Pertanika Journal of Social Sciences \& Humanities, 25(2), 647-662.

51. Rahman, M. M., Uddin, M. J., \& Rahaman, S. (2019). Work-family, family-work conflict and subjective well-being of commercial bank employees in Bangladesh: The moderating effects of organisational supports. Advances in Management and Applied Economics, 9(6), 77-96.

52. Raina, B., \&Kalse, A. (2018). A study of human resource practices on employee work engagement in hospitality industry. BVIMSR's Journal of Management Research, 10(2), 194-206.

53. Riemer, S., Thompson, H. and Burman, O.H., (2018). Behavioural responses to unexpected changes in reward quality. Scientific reports, 8(1), p.16652.

54. Ross, J.E. (2017). Total quality management: Text, cases, and readings. Routledge.

55. Salmina, M., Ding, A. Y., \& Yu, M. (2021). 

Vol. 03(1-2) 74-91 (2021)

Human Resources Strategy to Improve HR Competencies. Journal of Worker Competency and Performance (JWCP), 1(02), 1-9.

56. Sebastiampillai, S., \& Holm, V. U. (2017). The Effect of HR Practices on Employee and Customer Satisfaction-A Study of an Airport Infrastructure Manager (Master's thesis, NTNU).

57. Silva, H. M. S. V., \&Madushani, R. A. I. (2017). The impact of human resource competencies of front line employees on tourist arrivals of unclassified hotels in western province, Sri Lanka. Journal of Advanced Research in Social Sciences and Humanities, 2(1), 09-16.

58. Silvia, A. V. (2017). Comparative Analysis Regarding The Human Resources Motivation In The Hotel Industry. Annals Of'constantinbrancu si'university Of Targu-Jiu.Economy Series, (3).

59. Sobaih, A. E. E. (2018). Human resource management in hospitality firms in Egypt: Does size matter?. Tourism and Hospitality Research, 18(1), 38-48.

60. Sobaih, A. E. E., \&Hasanein, A. M. (2020). Herzberg's theory of motivation and job satisfaction: Does it work for hotel industry in developing countries?. Journal of Human Resources in Hospitality \& Tourism, 19(3), 319-343.

61. Su, L., Swanson, S.R. and Chen, X., (2016). The effects of perceived service quality on repurchase intentions and subjective wellbeing of Chinese tourists: The mediating role of relationship quality. Tourism Management, 52, pp.82-95.

62. Sun, S., Zheng, J., Schuckert, M., \& Law, R. (2019). Exploring the service quality of Airbnb. Tourism Analysis, 24(4), 531-534.

63. Tiago, F., Borges-Tiago, T., \&Couto, J. (2020).
Human resources role in hospitality service quality. Strategic innovative marketing and tourism, 81.

64. Tiwari, V., Srivastava, S., \& Kumar, D. (2019). Adoption of HRM practices: A practical modelcase study of a hotel. IOSR Journal of Business and Management (IOSR-JBM), 21(4), 59-63.

65. Ushakov, R. N., Kryukova, E. M., Khetagurova, V. S., Mukhomorova, I. V., \&Zelenov, V. V. (2020).Efficiency of hotel management. Training of specialists in hotel industry field. Journal of Environmental Management \& Tourism, 11(2 (42)), 388-395.

66. Vaismoradi, M., \&Snelgrove, S. (2019). Theme in qualitative content analysis and thematic analysis. In Forum Qualitative Sozialforschung/ Forum: Qualitative Social Research (Vol. 20, No. 3).

67. Wang, H., Kim, K.H., Ko, E., and Liu, H. (2016). Relationship between service quality and customer equity in traditional markets. Journal of Business Research, 69(9), pp.3827-3834.

68. Willie, P.A., Connor, D., Sole, J., Forgacs, G., Grieve, R., and Mueller, J. (2017). Human capital challenges in the hotel industry of Canada: finding innovative solutions. Worldwide Hospitality and Tourism Themes, 9(4), pp.402-410.

69. Wu, X., Wang, J., \& Ling, Q. (2021). Managing internal service quality in hotels: Determinants and implications. Tourism Management, 86, 104329.

70. Zhang, P. (2017). A Study of the Factors that Affect Employee Performance in the UK Hotels (Doctoral dissertation, California State Polytechnic University, Pomona). 